\title{
English Translation Strategies of Tourism Texts Under Skopos Theory
}

\author{
Bingqian Zhou \\ School of North China Electric Power University (Baoding), Hebei 071000, China \\ 751510097@qq.com
}

Keywords: Skopos Theory; Tourism Translation; Translation Strategy.

\begin{abstract}
The rapid development of China's economy and the construction of "the Belt and Road Initiative", have greatly promoted the development of Chinese tourism. Now, China has gradually become an important destination for foreign tourists. The construction of Xiongan New Area and the integration of Beijing, Tianjin and Hebei have promoted the development of their surrounding scenic spots' tourism and also tourism translation of those sites. This paper, based on the translation practice of Hu Mountain Scenic Spot in Baoding, Hebei Province, first analyzes the translation difficulties encountered in the process. Then, on the basis of Skopos theory, it further discusses the corresponding translation strategies.
\end{abstract}

\section{Introduction}

With the development of Chinese tourism industry, the status of tourism translation has become increasingly significant. Accordingly, the translation of tourist brochures is more common and more demanding. The tourism translation belongs to the category of publicity, and its aim is to spread Chinese culture to the world through translation. By properly translation, foreign tourists can have maximum feelings of brilliant Chinese civilization, and enhance their understanding of the beauty of Chinese historic and scenic spots. At the same time, a good translation would also facilitate tourists. From all above, tourism translation of high quality is essential to the development of Chinese tourism. So, based on the Skopos theory, this paper initially summarizes the difficulties encountered in the translation process, and then explores the corresponding methods of translation. Moreover, the analysis sample of the paper is the Hebei Quyang Hu Mountain Scenic Spot, which is near Xiongan New Area. Therefore, the methods used in this paper may provide some help to the translation of the surrounding scenic spots.

\section{A Brief Introduction to the Skopos Theory of Translation}

Hans Vermeer, German linguist and translation scholar, once put it, "Translation is a human act, and any act has a purpose"; "Translation is a purposive act". Therefore, "Translation is a text produced for a certain purpose and target audience in the target language context." The core concept of Skopos theory is that translation methods or strategies must be determined by the intended purpose or function of the target text. [1]

Therefore, the Skopos theory is not to emphasize the full equivalence between the target text and the source text. In other words, in the process of translation, it is the aim of translation that really matters and translators need to choose translation methods or strategies according to the purpose of translation. Furthermore, Peter Newmark put forward that, the translation purpose should follow three basic principles: Skopos rule, coherence rule and fidelity rule. [2] Among the three rules, the most important one is the Skopos rule. That is, the target text must be internally coherent, which means no matter what kind of methods or strategies are used, the target text should be understood by target readers. 


\section{Difficulties in the Translation Process}

\subsection{Differences between Chinese and Western languages}

English and Chinese belong to different language families. English belongs to the Indo-European language family, while Chinese belongs to the Sino-Tibetan language family. As a consequence, there are also differences between the two languages including the differences between "hypostasis" and "parataxis", complex and simple forms, active voice and passive voice, abstract and specific wording , differences in having inflections or not, parts of speech, and many other aspects. [1] Here is an example:

ST: 景区从林幽深, 瀑布飞流直下

TT: The scenic spot has deep jungles and waterfalls cascading down.

The above translation process embodies the differences between "hypostasis" and "parataxis", complex and simple forms of English and Chinese. The source text has gorgeous rhetoric, neat reunion, with the pursuit of beauty of artistic conception. Additionally, through vivid description, readers could have rich associations, which deepen their desire for travel. However, the target language emphasizes conciseness and objective presentation of information without too much language modifications. Therefore, translators should have a deep thought of conciseness and the reading habits of English readers when translating.

\subsection{Differences between Chinese and Western Cultures}

Because there are many differences in the way of thinking, habits of life, historical heritage and religious beliefs between English and Chinese nation, there are also many differences in the English and Chinese cultures. Besides, cultural differences may cause understanding barriers, which requires translators to pay attention to the cultural differences in the process of tourism translation, and to use translation strategies to deal with these. An instance of application is as follows:

ST: 据记载, 虎山淘金始于元代。当地民间传说, 在唐宋时期, 虎山就有采金活动, 一直 到上世纪九十年代中期。

TT: According to the records, the gold panning in Hu Mountain started in the Yuan Dynasty (1271 -1368). In the local folklore, the Hu Mountain started gold panning activities from the Tang and Song Dynasties (618 - 1279), which lasted until the mid-1990s.

The translation barrier here is Chinese dynasties. In the west, AD chronological method is used to record history. On the contrary, Chinese chronology is to use "dynasties" with different names as the names of different periods. Due to the culture difference, English readers do not have clear concept of Chinese dynasties. In order to make connections for them, translator needs to add explanations for the dynasty, in which the correspondent A.D. year is included. By doing this, it would be easier for English readers to understand what the exact time referred in the text.

\section{Translation Strategies}

\subsection{Literal Translation}

Literal translation is one of the most commonly used translation methods in the process of tourism translation, emphasizing the correspondence of literal meaning of the text. [2] When using the method, there is basically no need to deal with the source text accordingly. This method can, on the one hand, spread the culture of the source language for the target readers. On the other hand, there is a unique advantage in the field of tourism translation. This will help tourists ask the information of the tourist attractions, for instance, the location. The reason is obvious, literal translations of tourist attractions are similar to the expressions in the source language in the sound and grammar. Hence, local people of the tourist attractions are easier to understand the translation. Considering this, the names of scenic 
spot, food and etc. are often translated by literal translation method. And the next is an example of them:

$\mathrm{ST}$ : 虎山有很多景点，“金水泉”、“神仙瀑”、“许愿树”、“淘金洞”、“乌鸣 涧”、“矿工生活区”、“三连瀑”、“空中草甸”、“三尖梁”。

TT: There are many unique tourist attractions in $\mathrm{Hu}$ Mountain, such as "Jinshui Spring", "Immortal Falls", "Wishing Tree", "Gold Panning Cave", "Twittering Gully", "Living Quarter for Miner", "Three Successive Falls", "Meadow in the Air" and "Tricuspid Bridge".

The translation of all scenic spot names follows the principle of literal translation. On the one hand, it helps to spread the culture of scenic spots to foreign tourists. On the other hand, literal translation of sites' names is helpful for local service providers with primary English level to provide guidance services for foreign tourists. When foreign tourists encounter special situations like getting lost in the scenic spots, it is convenient for them to ask local people for help.

\subsection{Ellipsis}

In terms of the vocabulary of tourist texts, Chinese are different from English. Chinese favors dual words, and often uses four-character idiom, parallelism, etc., so as to enhance momentum and rhythm. Chinese also tends to use ornate rhetoric and exaggerated rhetoric to enrich the language. On the contrary, English tends to use concise and concrete words to express the original meaning faithfully. Therefore, in the process of tourism translation, without prejudice to the meaning of the original, the functional equivalence of translation may be achieved by deleting some modifiers of the source text. We may see this strategy through the following instance:

ST: 山中叮咚作响的 “金水泉” 奏响了虎山一曲天然之歌。泉水常年咕噜噜的冒泡, 清澈 甘甜的溪水上下翻腾, 一年四季冬温夏凉。

TT: The "Jinshui Spring" sings in the mountain, which plays natural sound. Here, the water bubbles all the year; the clean sweet river falls and rises; the climate is fairly mild in winter and rather cool in summer.

In the target text, the meaning of the source text is translated in a concise expression. The original modified elements such as "叮咚作响" and "咕噜噜的" are deleted, which is in line with the purpose of tourism translation and is helpful to the comprehension of English readers at the same time.

\subsection{Explanation}

Because of the cultural differences between Chinese and English Culture, sometimes it is difficult for foreign tourists to understand the collocation or sentence structure of Chinese tourist texts. [3] In order to accurately convey the cultural background information contained therein to tourists, and conform to the principle of functional equivalence, the translation stragety of explanation is needed. That means translator may have to add relevant explanations like the background knowledge to the target text without affecting target readers' reading, so as to make it easier for readers to understand the source text. The following is an application example of this strategy:

ST: 虎山是一片英雄的土地,当地流传着 “老虎吃羊” 的传说, 也就是洋鬼子走到这里，一 定会被虎山上的民兵给消灭掉。

TT: Hu Mountain is a land of heroes, where the legend of "tigers eat sheep (foreign invaders)" spreads. That is, if foreign invaders came here, they would be bound to be destroyed by the militias in Hu Mountain.

Although there are brief explanations behind in the source text, it is still difficult for foreign readers to figure out the connotative meaning of “羊” in the “老虎吃羊”. In Chinese, “羊” sounds like “洋”, which means “foreign invaders". Howbeit, without culture background, foreign readers cannot understand that. Therefore, the explanation is essential under this circumstance. 


\section{Summary}

Translation Skopos theory emphasizes the selection of translation methods according to the purpose of translation. Besides, the translation of tourism texts lays stress on the purpose of tourism application. Therefore, under the guidance of Skopos theory, the translation purposes of tourism can be better accomplished, which requires translators to adjust their translation strategies flexibly according to the intended functions of the target text. Under Skopos Theory, this paper analyzes the translation difficulties encountered in the English translation process of Baoding Quyang $\mathrm{Hu}$ Mountain Scenic spot in Hebei province, and then probes into the relevant literal translation methods - the literal translation strategy, ellipsis strategy and explanation strategy. The aim of the paper is to generalize translation methods, so as to adapt them to the tourism translation of surrounding scenic spots.

\section{References}

[1]. Qian Jiang, Gangqiang He. A Course in Translation Basics (2nd Edition) [M]. Shanghai: Shanghai Foreign Language Education Press, 2016:14; 40-44; 55-69; 94-95.

[2]. Ruihua Wu, Shuhui Xiong. Chinese-English Tourism Translation under Skopos Theory [J]. Journal of The House of Drama, 2017, 261(21):220-221.

[3]. Wenxu Hu. The translation of Tourist texts from the Point of View of Skopos Theory [J]. Journal of Northern literature, 2007, 28(3):217-218. 